Article

\title{
Two-Step Separation of Chitin from Shrimp Shells Using Citric Acid and Deep Eutectic Solvents with the Assistance of Microwave
}

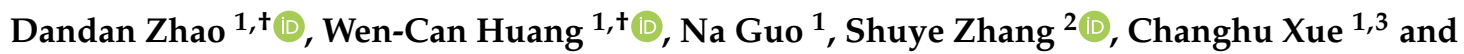 \\ Xiangzhao Mao $1,3, * \mathbb{D}$ \\ 1 College of Food Science and Engineering, Ocean University of China, Qingdao 266003, China; \\ Lizzy_Dan@163.com (D.Z.); hwc@ouc.edu.cn (W.-C.H.); gnaever@163.com (N.G.); xuech@ouc.edu.cn (C.X.) \\ 2 State Key Laboratory of Advanced Welding and Joining, Harbin Institute of Technology, Harbin 150001, \\ China; syzhang@hit.edu.cn \\ 3 Laboratory for Marine Drugs and Bioproducts, Qingdao National Laboratory for Marine Science and \\ Technology, Qingdao 266237, China \\ * Correspondence: xzhmao@ouc.edu.cn \\ + These authors contributed equally to this work.
}

Received: 14 January 2019; Accepted: 25 February 2019; Published: 3 March 2019

\begin{abstract}
In this research, a two-step extraction approach was developed for chitin preparation from shrimp shells by utilizing citric acids and deep eutectic solvents (DESs), which effectively removed minerals and proteins. In the first step, minerals of shrimp shells were removed by citric acid, and the demineralization efficiency reached more than $98 \%$. In the second step, the removal of protein was carried out using deep eutectic solvents with the assistance of microwave, and the deproteinization efficiency was more than $88 \%$. The results of scanning electron microscopy (SEM), Fourier transform infrared (FT-IR) spectroscopy, X-ray diffraction analysis (XRD), and thermogravimetric analysis (TGA) showed that the quality of DES-prepared chitin was comparable to that of traditional acid/alkali-prepared chitin. These results were realized without utilizing hazardous chemicals, which are detrimental to the environment. This research indicates that a DES-based preparation approach has the potential for application in the recovery of biopolymers from natural resources.
\end{abstract}

Keywords: chitin; shrimp shells; deep eutectic solvents; citric acids

\section{Introduction}

Chitin is considered the second most plentiful biopolymer in nature after cellulose [1]. It is a linear amino polysaccharide comprised of $\beta$-(1-4)-connected 2-deoxy-2-acetamido-D-glucose units [2]. The main source of chitin is crustacean shells derived from shrimp and crab [3]. Chitin is considered an important material because of its various characteristics, such as biodegradability, biocompatibility, non-toxicity, low immunogenicity, and thermal stability [4,5]. Therefore, chitin and its derivatives are widely used in cosmetic [6], food [7], agricultural [8], tissue engineering [9], waste water treatment [10], and packaging material applications [11]. It is reported that shrimp accounts for about $45 \%$ of processed seafood [12]. The shrimp processing industry produces massive amounts of by-products, such as shrimp shells. These shrimp by-products are usually applied for low-value animal feeds and biological fertilizers [13]. Therefore, it is particularly critical to convert by-products into high-value products. Shrimp shells are mainly composed of chitin, proteins, and minerals [14]. Chitin is extracted from shrimp shells by demineralization and deproteinization procedures.

In current industrial processing, methods for chitin preparation include chemical treatments, enzymatic reactions, and microbial fermentation $[1,15,16]$. Conventional chemical extraction of chitin 
requires strong acids and alkali to eliminate minerals and proteins [17]. However, using these harsh chemicals is detrimental to the environment. In addition, although enzymatic reactions and microbial fermentation methods avoid this drawback, the incomplete elimination of minerals and proteins limits the application of these methods [14].

Recently, chitin extraction by ionic liquids (ILs) from crustacean shells has been reported as an alternative method [14]. However, the main disadvantages of ILs are their high cost, toxicity, and complicated synthesis steps, which limit their application [18]. Deep eutectic solvents (DESs) are recognized as novel ionic liquid analogues [19]. DESs are composed of a hydrogen bond donor (HBD) and a hydrogen bond acceptor (HBA) that are capable of self-association by interactions with special hydrogen bonds to constitute a eutectic mixture with a lower melting point than those of every single ingredient $[20,21]$. Compared to ILs, DESs show similar physico-chemical characteristics while they are more advantageous because of their low price, non-toxicity, low flammability, and biodegradability $[19,22]$. Therefore, DESs are widely used in various applications, such as dissolution and extraction procedures, catalysis, organic synthesis, metal processing, electrochemistry, and analytical chemistry $[19,21]$. Moreover, studies have reported that DESs can also be used to dissolve and extract materials from natural products, such as phenolic compounds, biodiesel, starch, lignins, cellulose, and other carbohydrates [21,23].

In this work, the DESs composed of mixtures of betaine hydrochloride (betaine $\mathrm{HCl}$ )-urea, choline chloride ( $\mathrm{ChCl}$ )-urea, $\mathrm{ChCl}$-ethylene glycol, and $\mathrm{ChCl}$-glycerol were exploited to produce chitin with the assistance of microwave irradiation. To the best of our knowledge, the four DES systems have been widely used in various studies but there has been no attempt to obtain chitin from shrimp shells. Furthermore, the obtained chitin was examined by FT-IR, XRD, TGA, and SEM, and the reusability of DESs was also assessed.

\section{Materials and Methods}

\subsection{Materials}

The shrimp shells were dried in the oven at $90{ }^{\circ} \mathrm{C}$ and pulverized into powder with a particle size of $0.355 \mathrm{~nm}$ by using a grinder. Choline chloride were acquired from Yuanye Bio-Technology (Shanghai, China). Urea and coomassie brilliant blue G-250 were purchased from Solarbio (Shanghai, China). Betaine hydrochloride was purchased from Macklin (Shanghai, China). Ethylene glycol, glycerol, citric acid, hydrochloric acid, sodium hydroxide, lithium chloride ( $\mathrm{LiCl}$ ) and $\mathrm{N}, \mathrm{N}$-dimethylacetamide (DMAc) were acquired from Sinopharm Chemical Reagent Co., Ltd. (Shanghai, China).

\subsection{Synthesis of DESs}

In a typical process, the hydrogen bond donor (HBD) and acceptor (HBA) ingredients were mixed and heated at a certain temperature with magnetic stirring at an optimal ratio until homogenous and transparent solutions were obtained. Details of the preparation of the DESs are shown in Table 1. DESs used in this study are presented in Figure 1.

Table 1. List of the synthesis of deep eutectic solvents (DESs) used in this study.

\begin{tabular}{cccc}
\hline HBA & HBD & Molar Ratio (HBA:HBD) & Heating Temperature $\left({ }^{\circ} \mathbf{C}\right)$ \\
\hline Betaine $\mathrm{HCl}$ & Urea & $1: 2$ & 50 \\
$\mathrm{ChCl}$ & Urea & $1: 2$ & 60 \\
$\mathrm{ChCl}$ & Ethylene Glycol & $1: 2$ & 60 \\
$\mathrm{ChCl}$ & Glycerol & $1: 2$ & 90 \\
\hline
\end{tabular}




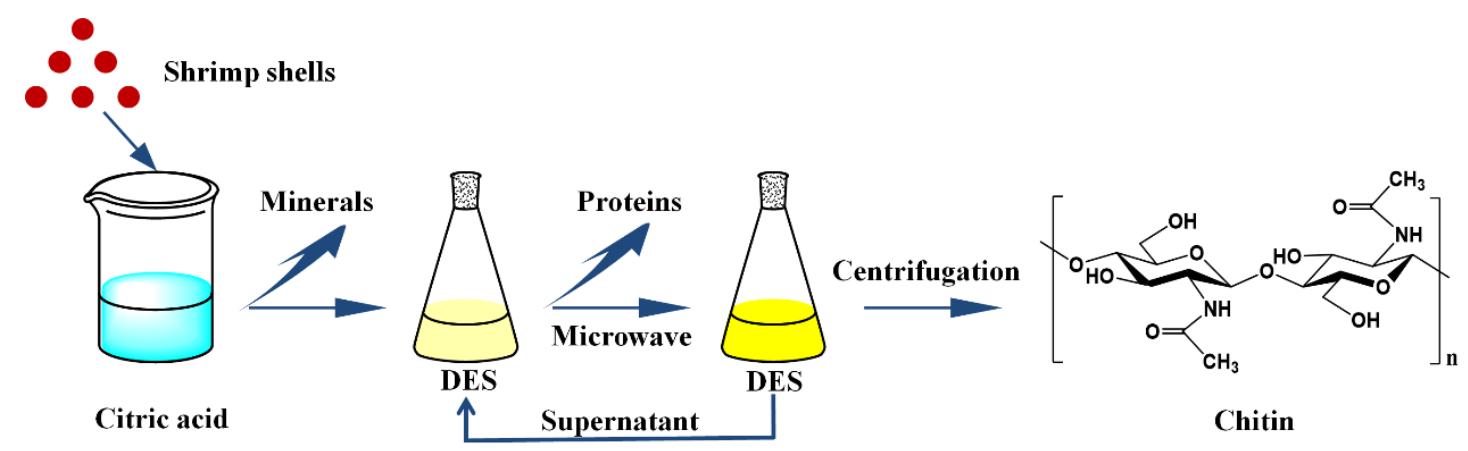

Figure 1. Schematic depiction of two-step separation of chitin from shrimp shells.

\subsection{Preparation of Chitin}

Figure 1 shows the schematic depiction of two-step separation of chitin from shrimp shells. Chitin preparation by utilizing citric acids and DESs was conducted as follows. The shrimp shells were treated with $10 \%$ citric acid for demineralization. The pretreated samples were dispersed in DESs with different shrimp shell/DES ratios of 1:5, 1:10,1:15, and 1:20. Then, the mixtures were heated by microwave irradiation at various times ( $1 \mathrm{~min}, 3 \mathrm{~min}, 5 \mathrm{~min}, 7 \mathrm{~min}$ and $9 \mathrm{~min}$ ). To avoid excessive heating of the mixtures, 2 to $3 \mathrm{~s}$ pulses were used, and the mixtures were stirred manually with a glass rod to ensure uniform dispersion of the shrimp shell powders in the DESs. Next, chitin and the DESs were separated via centrifugation. The chitin was gathered and rinsed with distilled water. The supernatants were collected for next use. After separation, the chitin was dried in an oven at $80^{\circ} \mathrm{C}$. The chitin yield was evaluated by calculating the ratio of the weight of extracted chitin to raw shrimp shells [24]. The DESs were used for five cycles without purification, and the recyclability of the DESs was assessed.

The mineral content was measured by the combustion of the sample $(1-2 \mathrm{~g})$ in a muffle furnace $\left(525^{\circ} \mathrm{C}\right)$ to a constant weight [25]. The demineralization (DM) efficiency was calculated according to the Equation (1):

$$
\operatorname{DM}(\%)=\left[\left(\mathrm{M}_{1}-\mathrm{M}_{2}\right) / \mathrm{M}_{1}\right] \times 100 \%
$$

where $M_{1}$ and $M_{2}$ represent the mineral content of the crude shrimp shells and prepared chitin, respectively.

The protein content of the samples was evaluated through the Bradford method [26]. The percentage of deproteinization (DP) was calculated according to the Equation (2):

$$
\mathrm{DP}(\%)=\left[\left(\mathrm{P}_{1}-\mathrm{P}_{2}\right) / \mathrm{P}_{1}\right] \times 100 \%
$$

where $P_{1}$ and $P_{2}$ represent the protein content of the crude shrimp shells and prepared chitin, respectively. All the above experiments were performed in triplicate.

For comparison with the DES-extracted chitin, acid/alkali extraction was conducted [7]. Demineralization was performed by adding $5 \%(w / v) \mathrm{HCl}$ solution to the shrimp shells $(30 \mathrm{~g})$. The mixtures were stirred for $1 \mathrm{~h}$ at ambient temperature. Afterwards the reacted samples were rinsed with distilled water and gathered by centrifugation. Next, deproteinization was performed by adding $10 \%$ $(w / v) \mathrm{NaOH}$ to the samples, and the mixtures were stirred for $2 \mathrm{~h}$ at $95^{\circ} \mathrm{C}$. The resulting samples were rinsed with distilled water until a neutral $\mathrm{pH}$ was achieved, and they were dried in an oven at $80^{\circ} \mathrm{C}$. 


\subsection{Characterization}

Chitin acetylation was determined by acid/alkali titration [27]. Dried sample of $0.2 \mathrm{~g}$ was dispersed in $30 \mathrm{~mL}$ of $0.1 \mathrm{M} \mathrm{HCl}$ solution and stirred for $1 \mathrm{~h}$. Then, the mixture was titrated with $0.1 \mathrm{M}$ $\mathrm{NaOH}$ solution. The degree of acetylation (DA) of chitin was expressed by the following equation:

$$
\operatorname{DA}(\%)=\left[1-\frac{\left(C_{1} V_{1}-C_{0} V_{0}\right) \times 0.016}{m \times(1-W) \times 0.0994}\right] \times 100 \%
$$

where $C_{1}$ and $C_{0}$ are the concentrations of $\mathrm{HCl}$ and $\mathrm{NaOH}$ solution in mol/L, respectively. $V_{1}$ and $V_{0}$ are the consumption volumes of $\mathrm{HCl}$ and $\mathrm{NaOH}$ solution in $\mathrm{ml}$, respectively. $\mathrm{m}$ is weight of the sample in g. $\mathrm{W}$ is moisture content of the sample in \%. 0.016 is molecular weight of $\mathrm{NH}_{2}$ in $1 \mathrm{~mL} 0.1 \mathrm{M} \mathrm{HCl}$ solution in g. 0.0994 is the theoretical $\mathrm{NH}_{2}$ content. The above experiment was repeated three times.

The molecular weight $(\mathrm{Mw})$ of prepared chitin was measured by a Ubbelohde viscometer (Shenbo Glass Instrument Co., Ltd., Shanghai, China) at $30^{\circ} \mathrm{C}$. Chitin was dissolved in $5 \%(w / w) \mathrm{LiCl} / \mathrm{DMAc}$ and prepared into different concentrations of chitin solutions (0.03-0.05 g/dL). The Mw was calculated using the Mark-Houwink-Sakurada equation [28].

$$
[\eta]=\mathrm{KM}_{\mathrm{w}}{ }^{\alpha}
$$

where $[\eta]$ represent intrinsic viscosity, $\mathrm{K}=7.6 \times 10^{-5} \mathrm{dL} / \mathrm{g}, \alpha=0.95$.

The surface morphologies of the samples were examined through utilizing a JEM-1200EX scanning electron microscope (SEM, JEOL, Tokyo, Japan). The samples were freeze-dried and then were covered with a platinum film (Pt coating) and linked to a metal stub before the detection. The samples were observed at an acceleration voltage of $10 \mathrm{kV}$.

The Fourier transform infrared spectra (FT-IR) of the samples were collected with a Nicolet iS10 spectrometer (Thermo Fisher Scientific, Massachusetts, USA) over the wavenumber between 4000 and $500 \mathrm{~cm}^{-1}$

The X-ray diffraction patterns (XRD) were conducted on a MinFlex 600 diffractometer (Bruker, Leipzig, Germany) using $\mathrm{Cu} \mathrm{K \alpha}$ radiation $(\lambda=1.54056 \mathrm{~nm}$ ) at $40 \mathrm{kV}$. The diffraction data were collected with a $2 \theta$ angle in the scope of $5^{\circ}$ to $60^{\circ}$ at a scanning rate of $5^{\circ} / \mathrm{min}$. The crystallinity index (CrI) was calculated as follows.

$$
\operatorname{CrI}(\%)=\left[\left(\mathrm{I}_{110}-\mathrm{I}_{\mathrm{am}}\right) / \mathrm{I}_{110}\right] \times 100 \%
$$

where $\mathrm{I}_{110}$ is the maximum intensity at $2 \theta \approx 20^{\circ}$, and $\mathrm{I}_{\mathrm{am}}$ is the intensity of amorphous diffraction peaks at $2 \theta \approx 16^{\circ}[29]$.

Thermogravimetric analysis (TGA) was analyzed by a 209 F3 thermogravimetric analyzer (NETZSCH, Serbia, Germany) at a heating rate of $10^{\circ} \mathrm{C} / \mathrm{min}$ in the scope of 30 to $1000{ }^{\circ} \mathrm{C}$ under a nitrogen atmosphere.

\section{Results and Discussion}

\subsection{Analysis of Demineralization and Deproteinization Effect of Shrimp Shells}

Shrimp shells consist mainly of chitin, protein and minerals. Chitin interacts with proteins to form chitin-protein fibers through specific hydrogen bonds [30]. The gap is full of proteins and minerals among the chitin-protein fibers [31,32]. The minerals are mainly composed of crystalline $\mathrm{CaCO}_{3}$. Pre-removal of minerals with citric acid helps DESs to weaken the network between chitin and proteins more easily, consequently breaking the connection within the inner structural organization of the shrimp shells. The extraction of high-purity chitin may be ascribed to the fact that DESs and shrimp shell components form hydrogen bonds, resulting in breaking the network of original hydrogen bonds in the shrimp shells. Finally, chitin is dispersed in the DESs and isolated from the proteins. 
The demineralization and deproteinization effect of citric acid and the DESs treatment were evaluated with different shrimp shell/DES ratios and microwave heating times. After pretreating shrimp shells with citric acid, the demineralization rate was $98.15 \pm 0.3 \%$. The deproteinization effect of DESs treatment is shown in Figure 2. The deproteinization effect increases with increasing of the shrimp shell/DES ratio from 1:5 to 1:20. This result demonstrates that the deproteinization effect could be improved at higher shrimp shell/DES ratios. Microwave heating time is also an important factor affecting the deproteinization rate. The deproteinization effect continuously improved with increasing microwave heating time, and no significant variation was observed after $7 \mathrm{~min}$ at all of the measured shrimp shell/DES ratios. The maximal deproteinization rates of betaine HCl-urea, ChCl-urea, ChCl-ethylene glycol, and ChCl-glycerol reached $93 \pm 0.8 \%, 92.0 \pm 1.2 \%, 90.6 \pm 1.4 \%$ and $88.6 \pm 1.1 \%$, respectively (Figure $2 \mathrm{a}-\mathrm{d}$ ). The yields of chitin extracted by betaine $\mathrm{HCl}-$ urea, $\mathrm{ChCl}$-urea, ChCl-ethylene glycol, and ChCl-glycerol were $23.6 \pm 0.6 \%, 25.1 \pm 1.3 \%, 24.8 \pm 0.7 \%$ and $22.5 \pm 1.0 \%$, respectively, which were higher than that of the acid/alkali-extracted chitin $(17.7 \pm 1.8 \%)$.
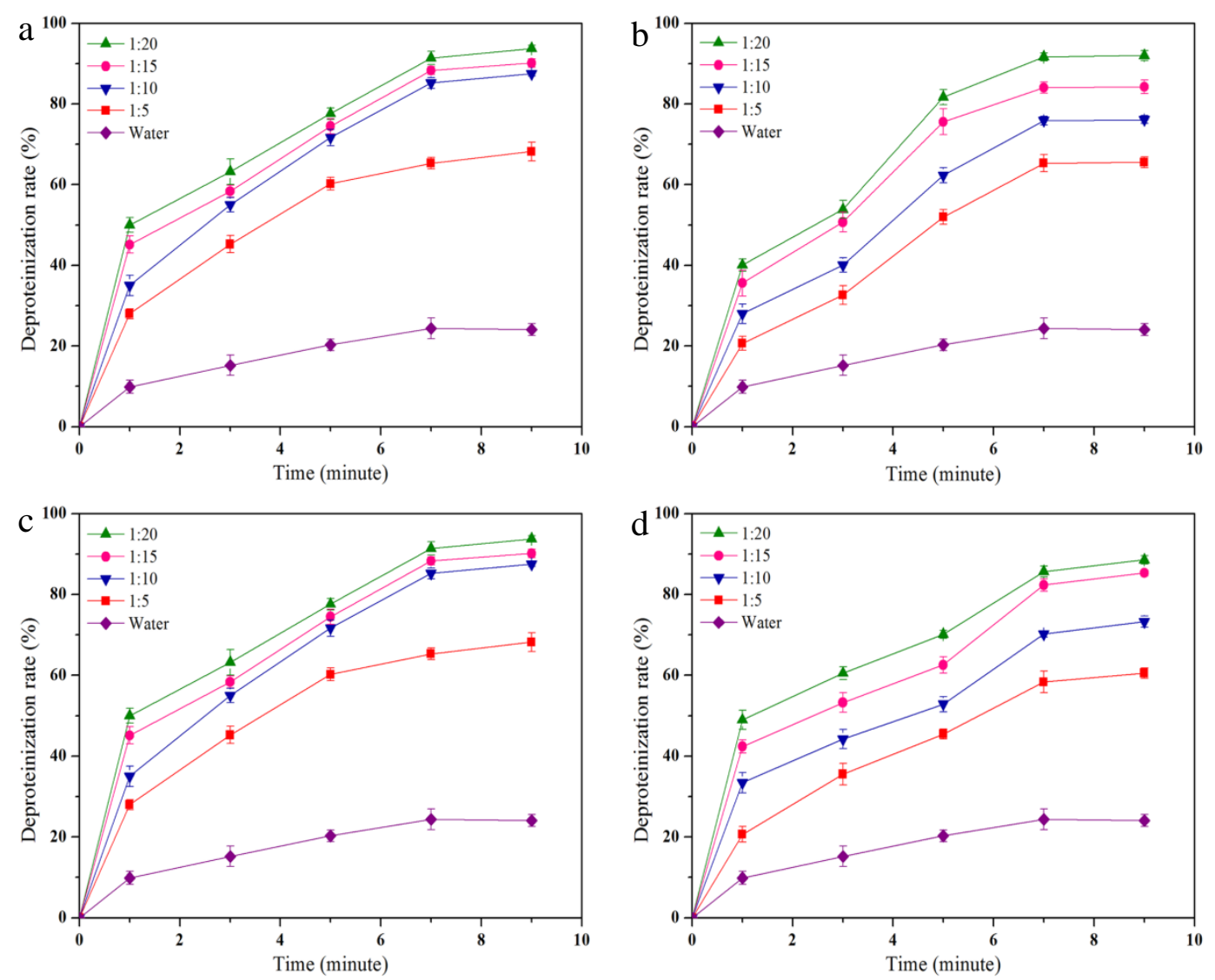

Figure 2. Deproteinization rates of (a) betaine $\mathrm{HCl}$-urea, (b) ChCl-urea, (c) ChCl-ethylene glycol, and (d) ChCl-glycerol at shrimp shell/NADES ratios of 1:5, 1:10, 1:15, and 1:20.

\subsection{The Degree of Acetylation (DA) of Chitin}

Acetylation is an important factor for measuring the quality of chitin. The degree of acetylation (DA) of the chitin extracted by betaine $\mathrm{HCl}$-urea, $\mathrm{ChCl}$-urea, $\mathrm{ChCl}$-ethylene glycol, and $\mathrm{ChCl}$-glycerol was $92.2 \pm 0.8 \%, 95.1 \pm 1.2 \%, 93.4 \pm 0.6 \%$, and $91.3 \pm 1.5 \%$, respectively. However, the DA of the chitin prepared by acid/alkali method was $86.12 \pm 1.4 \%$. This result shows that DESs did less damage to the acetyl groups of chitin than strong acid and alkali. In the process of acid/alkali extraction, the intermolecular hydrogen bond of chitin was weakened significantly, which made $\mathrm{NaOH}$ solution easier to contact and remove the acetyl groups of the chitin, resulting in a decrease in the DA. 


\subsection{The Molecular Weight (Mw) of Chitin}

The Mw of chitin is an important physicochemical property, which affects its application in various fields. The $\mathrm{Mw}$ of chitin extracted by betaine $\mathrm{HCl}$-urea, $\mathrm{ChCl}$-urea, $\mathrm{ChCl}$-ethylene glycol, and ChCl-glycerol was calculated to be $3.3 \times 10^{5}, 3.7 \times 10^{5}, 3.4 \times 10^{5}, 2.9 \times 10^{5}$, respectively; all of these were higher than that of the acid/alkali-extracted chitin $\left(2.5 \times 10^{5}\right)$. These results suggested that the extracted chitin molecules by the DESs with the assistance of microwave were less degraded than other methods due to the relatively mild reaction conditions.

\subsection{SEM}

SEM images of the shrimp shells, acid/alkali-prepared chitin, and DES-prepared chitin are presented in Figure 3. The morphology of the DES-prepared chitin (Figure 3c-f) exhibited high-density porous and fibrous structures, which were similar to those of the acid/alkali-prepared chitin (Figure 3b). On the contrary, the shrimp shells (Figure 3a) appear to have a rough surface without pores due to the presence of proteins and minerals [33]. The DES-extracted chitin show smooth surface characteristics with pores because of the elimination of proteins and minerals from the shrimp shells.
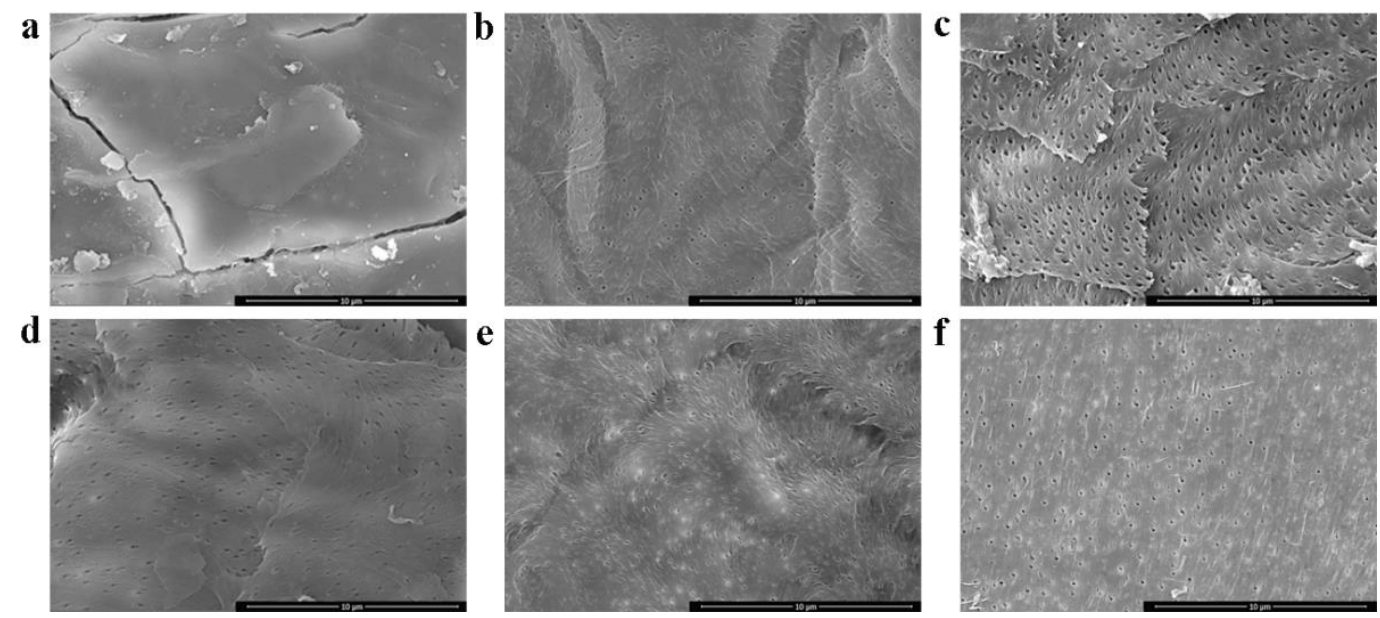

Figure 3. SEM images of (a) shrimp shells, (b) chitin extracted by the acid/alkali method, (c) chitin extracted by betaine $\mathrm{HCl}$-urea, (d) chitin extracted by $\mathrm{ChCl}$-urea, (e) chitin extracted by $\mathrm{ChCl}$-ethylene glycol, and (f) chitin extracted by ChCl-glycerol.

\subsection{FT-IR}

The FT-IR reports of the DES-prepared chitin, acid/alkali-prepared chitin, and shrimp shells are shown in Figure 4a. The FT-IR spectra of DES-extracted chitin are consistent with those of acid/alkali-extracted chitin. The absorption peak appearing at $3449 \mathrm{~cm}^{-1}$ is ascribed to O-H stretching vibration $\left(\mathrm{C}_{6}-\mathrm{OH} \ldots \mathrm{O}=\mathrm{C}\right)$ [34]. Two absorption bands at $3268 \mathrm{~cm}^{-1}$ and $3104 \mathrm{~cm}^{-1}$ are ascribed to the $\mathrm{N}-\mathrm{H}$ stretching restricted by intermolecular hydrogen bond $-\mathrm{C}=\mathrm{O} \ldots \mathrm{H}-\mathrm{N}$ - and the $\mathrm{NH}$ groups of intramolecular bonding [6,35]. The amide I band divided into two absorption peaks at $1661 \mathrm{~cm}^{-1}$ and $1625 \mathrm{~cm}^{-1}$, are generated by intra-chain hydrogen bonds with $\mathrm{NH}$ groups $(-\mathrm{C}=\mathrm{O} \ldots \mathrm{H}-\mathrm{N}-)$ and inter-chain hydrogen bonds with the primary $\mathrm{OH}\left(-\mathrm{C}=\mathrm{O}-\mathrm{HOCH}_{2}-\right)$ [36]. These are typical bands of $\alpha$-chitin. In addition, the absorption peaks of amide II that appear at $1560 \mathrm{~cm}^{-1}$ are generated by $\mathrm{C}-\mathrm{N}$ stretching and amide III at $1316 \mathrm{~cm}^{-1}$ assigned to $\mathrm{C}-\mathrm{H}$ bend [36]. For the spectrum of shrimp shell, the amide band at $1658 \mathrm{~cm}^{-1}$ is not clearly separated because of the overlapping of peaks of protein [37]. In contrast, an amide band was separated after DESs treatment, indicating that the proteins were eliminated from the shrimp shells. 

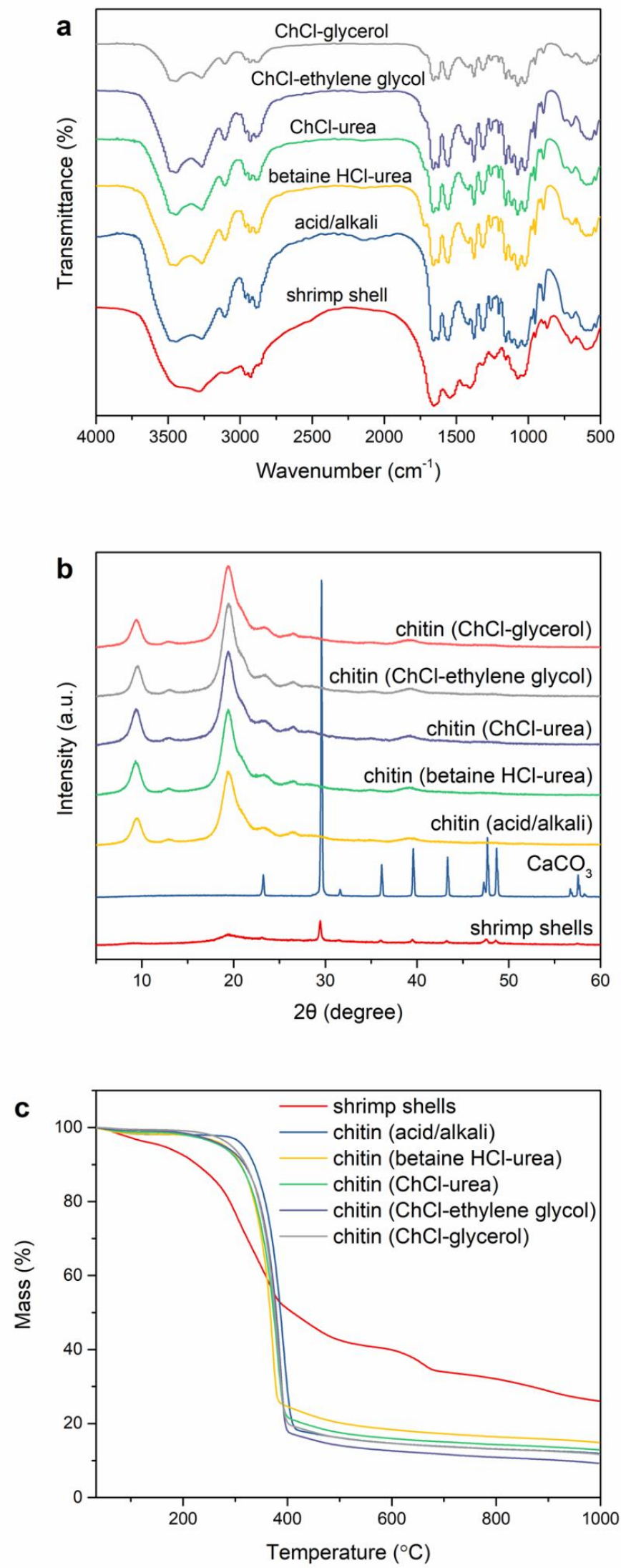

Figure 4. (a) FT-IR spectra of shrimp shells, acid/alkali-prepared chitin, and DES-prepared chitin; (b) XRD curves of the shrimp shells, $\mathrm{CaCO}_{3}$, acid/alkali-prepared chitin, and DES-prepared chitin; and (c) TG curves of the shrimp shells, acid/alkali-prepared chitin, and DES-prepared chitin. 


\section{6. $X R D$}

To evaluate the crystal structure and crystallinity of the samples, XRD analysis was conducted on the DES-prepared chitin, acid/alkali-prepared chitin, shrimp shells and $\mathrm{CaCO}_{3}$ (Figure $4 \mathrm{~b}$ ). Two main diffraction peaks at $9.3^{\circ}, 19.2^{\circ}[38]$, and weak diffraction peaks at $12.9^{\circ}, 23.4^{\circ}, 26.4^{\circ}$ were observed in the acid/alkali-prepared chitin and DES-prepared chitin [24,39]. These diffraction peaks are typical for the crystalline structure of $\alpha$-chitin. After the DES treatment, the intensity of the characteristic peaks of a-chitin increased, whereas the peak associated with $\mathrm{CaCO}_{3}$ at $29.6^{\circ}$ had disappeared in the DES-prepared chitin, suggesting that the $\alpha$-chitin concentration was increased by removing $\mathrm{CaCO}_{3}$. Moreover, the $\mathrm{CrI}$ indexes of the chitin extracted by betaine $\mathrm{HCl}$-urea, $\mathrm{ChCl}$-urea, $\mathrm{ChCl}$-ethylene glycol, and $\mathrm{ChCl}$-glycerol were $70.8 \%, 81.0 \%, 80.8 \%$, and $69.5 \%$, respectively. The relatively low crystallinity of the chitin extracted by betaine $\mathrm{HCl}$-urea and ChCl-glycerol can be attributed to the breaking of intramolecular and intermolecular hydrogen bonds and the formation of amorphous chitin $[40,41]$. The decrease in crystallinity of acid/alkali-extracted chitin $(65.4 \%)$ is due to the swelling of chitin caused by $\mathrm{HCl}$ and $\mathrm{NaOH}$, which makes it easier for them to enter into the chitin molecule, resulting in a larger crystal plane distance. The CrI index of the shrimp shells was found to be $48.3 \%$, which is lower than that of the DES-extracted chitin. Overall, the increase in crystallinity indicated that calcium carbonate and proteins were eliminated from the shrimp shells through citric acid and DES treatment.

\subsection{TGA}

TGA examination of the samples was conducted to evaluate their thermal stability. Figure 4c shows TGA curves for the shrimp shells, acid/alkali-prepared chitin, and DES-prepared chitin. The initial slight decomposition before $100{ }^{\circ} \mathrm{C}$ was related to the evaporation of chemisorbed water [39]. The second stage of degradation at 100 to $250{ }^{\circ} \mathrm{C}$ was largely due to the breakdown of proteins and lipids [27]. In the third decomposition stage the samples showed large weight losses at $250-400{ }^{\circ} \mathrm{C}$, which was attributed to the decomposition of chitin. The final weight loss in the shrimp shells between 600 and $700{ }^{\circ} \mathrm{C}$ resulted from the conversion of $\mathrm{CaCO}_{3}$ to $\mathrm{CaO}$ and $\mathrm{CO}_{2}$ [27]. Moreover, The TGA results of the DES-prepared chitin were consistent with those of the acid/alkali-prepared chitin, and they only showed two independent decomposition stages, namely, the evaporation of chemisorbed water and decomposition of chitin. This reveals that the chitin pretreated with citric acid was free from minerals and proteins were eliminated from shrimp shells by the DESs.

\subsection{Reusability}

As seen in Figure 5, the deproteinization rate slightly decreased after 3 cycles; however, as the number of cycles continued to increase, the deproteinization rate was significantly reduced. With the increase in reuse times, the formation of hydrogen bonds in DESs may be destroyed, resulting in poor thermal stability and low solubility, so that chitin cannot be well dissolved in DES. The betaine $\mathrm{HCl}$-urea exhibited better reusability than the others. After 5 reaction cycles, the DESs became too viscous to be further reused, which might be due to the presence of proteins and other impurities in the recycled DESs. 


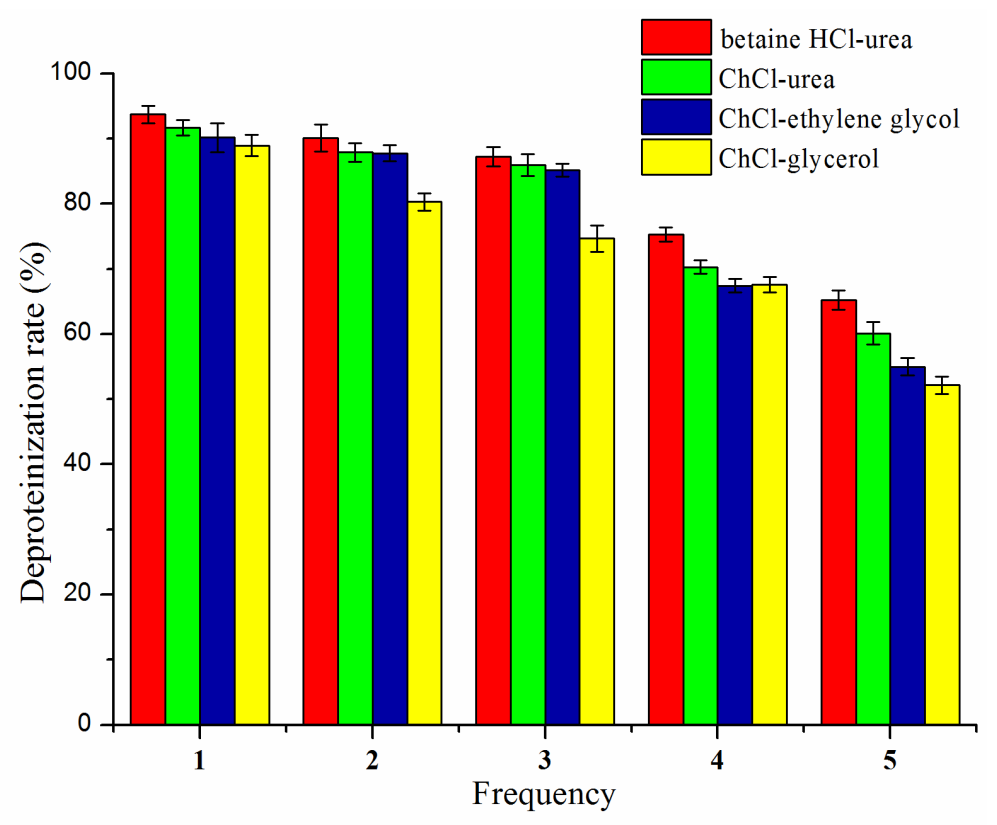

Figure 5. Reusability of the DESs.

\section{Conclusions}

In this research, a two-step extraction approach was developed and shown to be effective for chitin preparation from shrimp shells. The results showed that the demineralization rate and deproteination rate were excellent. The DA of the chitin extracted by the DESs exceeded 91\%. The outcomes of SEM, FT-IR, XRD, and TGA analysis of DES-prepared chitin were similar to those of chitin prepared through the traditional acid/alkali approach, and no significant degradation of chitin occurred during the extraction process. In addition, the DESs could be reused five times. DES-based preparation avoids the utilization of harsh chemicals, which are detrimental to the environment. Taken together, this research provides an environmentally protective and effective method for chitin preparation from crustacean shells.

Author Contributions: Conceptualization, C.X., X.M. and S.Z.; Methodology, D.Z., W.-C.H. and X.M.; Formal Analysis, W.-C.H. and N.G.; Data Curation, D.Z., W.-C.H. and N.G.; Writing-Original Draft Preparation, D.Z.; Writing-Review \& Editing, W.-C.H., D.Z. and X.M.; Visualization, D.Z., W.-C.H. and X.M.; Supervision, X.M. and S.Z.; Project Administration, C.X. and X.M.

Funding: This research was supported through the China Agriculture Research System (CARS-48), Major Special Science, Technology Projects in Shandong Province (2016YYSP016), and Ningbo Science and Technology Projects (2017C110006), and Taishan scholar project.

Conflicts of Interest: The authors declare no conflict of interest.

\section{References}

1. Mao, X.; Guo, N.; Sun, J.; Xue, C. Comprehensive utilization of shrimp waste based on biotechnological methods: A review. J. Clean. Prod. 2017, 143, 814-823. [CrossRef]

2. Shen, X.; Shamshina, J.L.; Berton, P.; Bandomir, J.; Wang, H.; Gurau, G.; Rogers, R.D. Comparison of Hydrogels Prepared with Ionic-Liquid-Isolated vs Commercial Chitin and Cellulose. ACS Sustain. Chem. Eng. 2016, 4, 471-480. [CrossRef]

3. Roberts, G.A.F. Thirty years of progress in chitin and chitosan. Prog. Chem. Appl. Chitin Deriv. 2008, 13, 7-15.

4. Pillai, C.K.S.; Paul, W.; Sharma, C.P. Chitin and chitosan polymers: Chemistry, solubility and fiber formation. Prog. Polym. Sci. 2009, 34, 641-678. [CrossRef]

5. Rinaudo, M. Chitin and chitosan: Properties and applications. Prog. Polym. Sci. 2006, 31, 603-632. [CrossRef]

6. Wang, W.-T.; Jiang, Z.; Wang, X.-L.; Huang, Y.; Wang, Y.-Z. Dissolution Behavior of Chitin in Ionic Liquids. J. Macromol. Sci. B 2010, 49, 528-541. [CrossRef] 
7. Kumari, S.; Rath, P.; Sri Hari Kumar, A.; Tiwari, T.N. Extraction and characterization of chitin and chitosan from fishery waste by chemical method. Environ. Technol. Innov. 2015, 3, 77-85. [CrossRef]

8. Park, B.K.; Kim, M.M. Applications of Chitin and Its Derivatives in Biological Medicine. Int. J. Mol. Sci. 2010, 11, 5152-5164. [CrossRef] [PubMed]

9. Suh, J.-K.F.; Matthew, H.W.T. Application of chitosan-based polysaccharide biomaterials in cartilage tissue engineering: A review. Biomaterials 2000, 21, 2589-2598. [CrossRef] [PubMed]

10. Bhatnagar, A.; Sillanpää, M. Applications of chitin-and chitosan-derivatives for the detoxification of water and wastewater-a short review. Adv. Colloid Interface 2009, 152, 26-38. [CrossRef] [PubMed]

11. Leceta, I.; Guerrero, P.; Cabezudo, S.; Caba, K.D.L. Environmental assessment of chitosan-based films. J. Clean. Prod. 2013, 41, 312-318. [CrossRef]

12. Sagheer, F.A.A.; Al-Sughayer, M.A.; Muslim, S.; Elsabee, M.Z. Extraction and characterization of chitin and chitosan from marine sources in Arabian Gulf. Carbohydr. Polym. 2009, 77, 410-419. [CrossRef]

13. Nguyen, T.T.; Zhang, W.; Barber, A.R.; Su, P.; He, S. Microwave-intensified enzymatic deproteinization of Australian rock lobster shells (Jasus edwardsii) for the efficient recovery of protein hydrolysate as food functional nutrients. Food Bioprocess Technol. 2016, 9, 628-636. [CrossRef]

14. Setoguchi, T.; Kato, T.; Yamamoto, K.; Kadokawa, J.-I. Facile production of chitin from crab shells using ionic liquid and citric acid. Int. J. Biol. Macromol. 2012, 50, 861-864. [CrossRef] [PubMed]

15. Beaney, P.; Jaime, L.-M.; Healy, M. Comparison of chitins produced by chemical and bioprocessing methods. J. Chem. Technol. Biotechnol. 2005, 80, 6. [CrossRef]

16. Younesa, I.; Ghorbel-Bellaaj, O.; Nasri, R.; Chaabouni, M.; Rinaudo, M.; Nasri, M. Chitin and chitosan preparation from shrimp shells using optimized enzymatic deproteinization. Process Biochem. 2012, 47, 2032-2039. [CrossRef]

17. Percot, A.; Viton, C.; Domard, A. Optimization of chitin extraction from shrimp shells. Biomacromolecules 2003, 4, 12-18. [CrossRef] [PubMed]

18. Pinkert, A.; Marsh, K.N.; Pang, S.; Staiger, M.P. Ionic Liquids and Their Interaction with Cellulose. Chem. Rev. 2009, 109, 6712-6728. [CrossRef] [PubMed]

19. Smith, E.L.; Abbott, A.P.; Ryder, K.S. Deep eutectic solvents (DESs) and their applications. Chem. Rev. 2014, 114, 11060-11082. [CrossRef] [PubMed]

20. Abbott, A.P.; Boothby, D.; Capper, G.; Davies, D.L.; Rasheed, R.K. Deep eutectic solvents formed between choline chloride and carboxylic acids: Versatile alternatives to ionic liquids. J. Am. Chem. Soc. 2004, 126, 9142-9147. [CrossRef] [PubMed]

21. Zhang, Q.; Vigier, K.D.O.; Royer, S.; Jerome, F. Deep eutectic solvents: Syntheses, properties and applications. Chem. Soc. Rev. 2012, 41, 7108-7146. [CrossRef] [PubMed]

22. Lee, Y.R.; Row, K.H. Comparison of ionic liquids and deep eutectic solvents as additives for the ultrasonic extraction of astaxanthin from marine plants. J. Ind. Eng. Chem. 2016, 39, 87-92. [CrossRef]

23. Dai, Y.; Spronsen, J.; Witkamp, G.J.; Verpoorte, R.; Choi, Y.H. Ionic liquids and deep eutectic solvents in natural products research: Mixtures of solids as extractionsolvents. J. Nat. Prod. 2013, 76, 2162-2173. [CrossRef] [PubMed]

24. Zhu, P.; Gu, Z.; Hong, S.; Lian, H. One-pot production of chitin with high purity from lobster shells using choline chloride-malonic acid deep eutectic solvent. Carbohydr. Polym. 2017, 177, 217-223. [CrossRef] [PubMed]

25. Qin, Y.; Lu, X.; Sun, N.; Rogers, R.D. Dissolution or extraction of crustacean shells using ionic liquids to obtain high molecular weight purified chitin and direct production of chitin films and fibers. Green Chem. 2010, 12, 968-971. [CrossRef]

26. Kruger, N.J. The Bradford method for protein quantitation. Methods Mol. Biol. 1994, 32, 9-15. [CrossRef] [PubMed]

27. Shamshina, J.L.; Barber, P.S.; Gurau, G.; Griggs, C.S.; Rogers, R.D. Pulping of Crustacean Waste using Ionic Liquids: To Extract or Not to Extract? ACS Sustain. Chem. Eng. 2016, 4, 6072-6081. [CrossRef]

28. Poirier, M.; Charlet, G. Chitin fractionation and characterization in $N, N$-dimethylacetamide/lithium chloride solvent system. Carbohydr. Polym. 2002, 50, 363-370. [CrossRef]

29. Kaya, M.; Seyyar, O.; Baran, T.; Erdoğan, S.; Kar, M. A physicochemical characterization of fully acetylated chitin structure isolated from two spider species: With new surface morphology. Int. J. Biol. Macromol. 2014, 65, 553-558. [CrossRef] [PubMed] 
30. Vincent, J.F.V. Arthropod cuticle: A natural composite shell system. Compos. Part A 2002, 33, 1311-1315. [CrossRef]

31. Huang, W.; Zhao, D.; Guo, N.; Xue, C.; Mao, X. Green and Facile Production of Chitin from Crustacean Shells Using a Natural Deep Eutectic Solvent. J. Agric. Food Chem. 2018, 66, 11897-11901. [CrossRef] [PubMed]

32. Raabe, D.; Sachs, C.; Romano, P. The crustacean exoskeleton as an example of a structurally and mechanically graded biological nanocomposite material. Acta Mater. 2005, 53, 4281-4292. [CrossRef]

33. Gopi, S.; Balakrishnan, P.; Pius, A.; Thomas, S. Chitin nanowhisker (ChNW)-functionalized electrospun PVDF membrane for enhanced removal of Indigo carmine. Carbohydr. Polym. 2017, 165, 115-122. [CrossRef] [PubMed]

34. Sharma, M.; Mukesh, C.; Mondal, D.; Prasad, K. Dissolution of $\alpha$-chitin in deep eutectic solvents. RSC Adv. 2013, 3, 18149-18155. [CrossRef]

35. Cárdenas, G.; Cabrera, G.; Taboada, E.; Miranda, P. Chitin characterization by SEM, FTIR, XRD, and ${ }^{13} \mathrm{C}$ cross polarization/mass angle spinning NMR. J. Appl. Polym. Sci. 2004, 93, 1876-1885. [CrossRef]

36. Zhu, C.; Richardson, R.M.; Song, Y.; Rahatekar, S.S. One Step Dissolution, Extrusion, and Fiber Spinning of Chitin Using Ionic Liquid Solvents. In Polysaccharide-Based Fibers Composites; Springer: Cham, Switzerland, 2018; pp. 13-27. [CrossRef]

37. Kaznowska, E.; Depciuch, J.; Szmuc, K.; Cebulski, J. Use of FTIR spectroscopy and PCA-LDC analysis to identify cancerous lesions within the human colon. J. Pharm. Biomed. Anal. 2017, 134, 259-268. [CrossRef] [PubMed]

38. Kadokawa, J.; Hirohama, K.; Mine, S.; Kato, T.; Yamamoto, K. Facile Preparation of Chitin/Cellulose Composite Films Using Ionic Liquids. J. Polym. Environ. 2012, 20, 37-42. [CrossRef]

39. Kaya, M.; Sargin, I.; Tozak, K.O.; Baran, T.; Erdogan, S.; Sezen, G. Chitin extraction and characterization from Daphnia magna resting eggs. Int. J. Biol. Macromol. 2013, 61, 459-464. [CrossRef] [PubMed]

40. Gbenebor, O.P.; Adeosun, S.O.; Lawal, G.I.; Jun, S.; Olaleye, S.A. Acetylation, crystalline and morphological properties of structural polysaccharide from shrimp exoskeleton. Eng. Sci. Technol. 2017, 20, 1155-1165. [CrossRef]

41. Chen, C.; Yano, H.; Li, D.; Abe, K. Preparation of high-strength $\alpha$-chitin nanofiber-based hydrogels under mild conditions. Cellulose 2015, 22, 2543-2550. [CrossRef] 